\title{
Molecular Biotyping, Phylogenetic Analysis of Indole Acetic Acid Producing Rhizobium Sp. CU8 and Co-inhabitant Non-rhizobial Nodule Associated Bacteria From Mimosa Pudica L.
}

\section{Maya R.}

University of Calicut

YUSUF AKKARA ( $\square$ akkara69@yahoo.co.in )

University of Calicut https://orcid.org/0000-0002-1931-5278

\section{Research Article}

Keywords: Nitrogen fixers, Phylogenetic analysis, Plant growth promoters, Root nodule, 16S rRNA

Posted Date: August 23rd, 2021

DOl: https://doi.org/10.21203/rs.3.rs-810699/v1

License: (a) (1) This work is licensed under a Creative Commons Attribution 4.0 International License. Read Full License 


\section{Abstract}

The interaction between rhizobia and other nodule associated bacteria assist to mitigate nutrient stress in leguminous plants by fixing atmospheric nitrogen and synthesizing plant growth regulators. Beneficial effects of microbial inoculants emphasize the need for further research and their use in modern agriculture. The present work describes the isolation, identification, plant growth promoting properties and phylogenetic analysis of nodule associated bacteria from Mimosa pudica L. Isolation and characterization of nodule associated bacteria were done according to standard procedures. Molecular characterization of the isolates was performed using $16 \mathrm{~S}$ ribosomal RNA. Plant growth promoting ability was analyzed by quantifying the levels of Indole acetic acid. Evolutionary distance and relatedness was analyzed using neighbor joining method. Rhizobium sp. CU8 and three other co-resident non-rhizobial nodule associated bacteria (Bacillus cereus MY5, Ralstonia pickettii MY1 and Lactococcus lactis MY3) exhibiting nitrogen fixation, plant growth promotion and other potential microbial activities were characterized. Phylogenetic analysis revealed the genetic relatedness and evolutionary significance of Rhizobium sp. CU8 and other co-inhabitant non-rhizobial nodule associated bacteria from M. pudica. Present study identified the four isolates as potential biofertilizers due to their nitrogen fixing and growth promoting characteristics. L. lactis MY3 is the first co-resident nitrogen fixer and plant growth promoter reported from the root nodules of $M$. pudica.

\section{Introduction}

The members of Leguminosae, are associated with endophytic, root nodule associated bacteria (NAB) which ameliorates nutrient stress by fixing atmospheric nitrogen $\left(\mathrm{N}_{2}\right)$ and producing plant growth promoters. The genus Mimosa received considerable attention in the recent years because of its potential to fix atmospheric nitrogen. Biological nitrogen fixation is ecologically important, contributing 100290 million tons of nitrogen annually to the natural ecosystem and enhancing the growth of agronomically important forage and crop plants. Biological nitrogen fixation (both symbiotic and nonsymbiotic) reduces the use of synthetic nitrogen fertilizers.

Plant growth promoting bacteria (PGPB) enhance plant growth by fixing atmospheric nitrogen and its assimilation to the plant, production of siderophores to chelate iron and its absorption, solubilization of minerals such as phosphorus, synthesis of phytohormones, augmenting plant nutrient uptake (Glick 1995; Kloepper 1992) and the production of substances like antibiotics (Glick 1995). In addition, the PGP microbes express abiotic stress tolerance like extreme temperature, drought, salinity, $\mathrm{pH}$, heavy metal and pesticide pollution (Gopalakrishnan et al. 2015).

PGPB has beneficial effects on legume growth and some strains enhance the nodulation and nitrogen fixation by effective interaction between plant and rhizobia (Parmar and Dadarwal 1999). Most of the nodulating bacteria are free-living rhizobacteria, however, some are intracellular or intercellular endophytes (Sturz et al. 2000) and gain advantage of being protected from environmental stresses and microbial competition (Kobayashi and Palumbo 2000). The endophytes and epiphytes are the two 
different types of plant growth promoting rhizobia associated with host tissue. There are many endophytic and epiphytic bacteria which are directly or indirectly involved in plant growth and development. Endophytic bacteria live in plant tissues without affecting the normal metabolism of the host or gaining any benefit other than a noncompetitive environment inside the host. It has been demonstrated that bacterial endophytes have beneficial effects on host plants, such as growth promotion and biological control of pathogens (Downing and Thomson 2000; Ryu et al. 2005; Sturz et al. 1999). Legume root nodules may contain microbes other than rhizobia (Martínez-Hidalgo and Hirsch 2017; Zgadzaj et al. 2015), however, the function of these co-residents in the nodules is yet to be fully elucidated, their main role might be to assist rhizobia during the nodule infection process and to promote plant growth (Chibeba et al. 2020; Peix et al. 2015).

Modern agriculture faces challenges, such as loss of soil fertility, fluctuating climatic factors and increasing pathogen and pest attacks. Sustainability and environmental safety of agricultural production relies on eco-friendly approaches like use of biofertilizers, biopesticides and crop residue recycling. From the agricultural and ecological viewpoints, "how can we increase food quality and quantity, and to improve the sustainable plant productivity, while maintaining environmental quality?" the importance of nitrogen fixing and plant growth promoting bacteria, their gene conservation can contribute better in sustainable agriculture and $16 \mathrm{~S}$ ribosomal RNA typing is used to identify microorganisms. The $16 \mathrm{~S}$ rRNA based phylogenetic analysis revealed the distribution of genotypes in Rhizobium sp., B. cereus, R. pickettii and $L$. lactis. Our understanding of microbial interactions in the rhizosphere must be complemented by combining the basic and applied studies.

The beneficial effects of microbial inoculants, particularly nitrogen fixing and plant growth promoters (PGP), from the root nodule of $M$. pudica accentuate the need for research and its application in modern agriculture. The present study is focused on the isolation, identification, characterization, screening and comprehensive evaluation on phylogenetic relationship based on 16S rRNA gene of potential nitrogen fixers and plant growth promoters from root nodule of $M$. pudica.

\section{Materials And Methods}

\section{Isolation of nodule associated bacteria}

Bacteriae were isolated from the root nodules of $M$. pudica grown in different locations in the University of Calicut campus (geographic coordinates: $11^{\circ} 08^{\prime} 01.0^{\prime \prime} \mathrm{N}, 75^{\circ} 53^{\prime} 19.0^{\prime \prime} \mathrm{E} ; 11^{\circ} 08^{\prime} 00.4^{\prime \prime} \mathrm{N}, 75^{\circ} 53^{\prime} 17.5^{\prime \prime} \mathrm{E}$ ). The nodule associated bacteria (NAB), were isolated from healthy pink coloured root nodules, washed thoroughly using running tap water, surface sterilized using $70 \%(\mathrm{v} / \mathrm{v})$ ethanol for $30 \mathrm{~s}, 0.1 \%(\mathrm{w} / \mathrm{v}) \mathrm{HgCl}_{2}$ for $2 \mathrm{~min}$ and washed thrice with sterile double distilled water under aseptic condition for one min (Rajendran et al. 2012). Nodules were crushed using a sterile glass rod and the extracts were plated on to Yeast Mannitol agar medium ( $\mathrm{pH} 6.8)$, supplemented with Congo red dye $\left(0.025 \mathrm{gl}^{-1}\right)$. The cultures were incubated at $28 \pm 2^{\circ} \mathrm{C}$ for $24-48 \mathrm{hrs}$. Single colony-forming units were checked for purity by repeated 
transfer on to nutrient agar medium pH-7(Vincent 1970). Pure cultures were maintained on nutrient agar medium with regular subculturing and used for analysis.

\section{CHNS analysis}

Soil samples collected from the rhizosphere of M. pudica was used for CHNS elemental analysis using a Euro Vector CHNS Analyser Model No: Ea 3000. Instrument parameters were carrier pressure $100 \mathrm{kPa}$, purge flow $80 \mathrm{~mL} / \mathrm{min}$, oxygen flow $20 \mathrm{~mL}$ and run for $7 \mathrm{~min}$. Temperature of front furnace was $980^{\circ} \mathrm{C}$ and GC oven temperature was $105^{\circ} \mathrm{C}$. Sample (8.5-9.5 mg) was used for the analysis.

\section{Phenotypic characterization}

Bacterial isolates grown in nutrient agar medium were subjected to phenotype characterization based on the morphological and biochemical characters examined using Bergey's manual of systematic bacteriology (Bergeys 2001). The morphological characters were analysed using gram staining, motility test by hanging drop method and endospore staining by malachite green method using a phase contrast microscope. Biochemical analysis was performed using indole production, hydrolysis of urea, methyl red (MR) test, voges proskauer (VP), citrate utilization and nitrate reduction test. The Intrinsic antibiotic resistance of the isolates was determined by disc method with Ampicillin (Amp) (10 mcg/disc), Tetracycline (TE) (30 mcg/disc), and Penicillin G (PG) (10 IU/disc) (Cappuccino and Sherman 1983).

\section{Molecular characterization}

\section{DNA extraction, 16S ribosomal RNA typing and sequencing}

Genomic DNA of the three species was extracted and purified using CTAB method (Ausubel et al. 1995). The purified DNA was quantified using a Nanodrop 2000 spectrometer (UV scanning Thermo scientific). PCR amplification of the $16 \mathrm{~S}$ rRNA gene fragment was carried out using the universal primers 1-27F (AGAGTTTGATCCTGGCTCAG) and 1495R (CTACGGCTACCTGTTACGA) (Lane 1991) at an annealing temperature of 50खC. The band size was verified using agarose gel electrophoresis. The PCR products were cleaned and sequenced from Agrigenome Lab Pvt Ltd, Cochin, Kerala. Cloned 16S rRNA sequences were minimally edited and manually aligned using Bioedit software. Species identification and homology between the sequences were identified using BLAST (https://www.ncbi.nlm.nih.gov/BLAST/). The cloned sequences were submitted to GenBank, NCBI.

\section{Characterization of plant growth promoting potential of bacterial isolates}

Plant growth enhancement potential of the four isolates was verified by the production of indole acetic acid, organic acid and capacity to fix atmospheric nitrogen in plants.

\section{(a). Production of indole acetic acid (IAA)}

The isolates with IAA production capacity was identified using bacterial culture grown in nutrient broth supplemented with $0.1 \% \mathrm{~L}-$ Tryptophan(w/v) incubated at $30 \otimes \mathrm{C}$ for $48 \mathrm{hrs}$. Indole acetic acid (IAA) 
production was analysed using colorimetric method of Gordon and Weber (1951). IAA in the culture was quantified using standard calibration curve prepared using gradient concentrations of IAA.

\section{(b). Production of organic acid}

Assessed by growing bacterial culture in calcium carbonate agar $\left[\mathrm{CaCO}_{3} 5 \mathrm{gl}^{-1}, \mathrm{glucose} 5 \mathrm{gl}^{-1}\right.$, yeast extract $5 \mathrm{gl}^{-1}$, agar $\left.15 \mathrm{gl}^{-1}\right]$ medium and the clear zone around the colony confirmed the production of organic acid.

\section{(c). Assessment of nitrogen fixation}

The $\mathrm{N}_{2}$ fixation capacity was evaluated by growing the cultures in nitrogen free malate containing bromothymol blue medium [DL- Malic acid $5 \mathrm{gl}^{-1}, \mathrm{KOH} 4 \mathrm{gl}^{-1}, \mathrm{~K}_{2} \mathrm{HPO}_{4} 0.5 \mathrm{gl}^{-1}, \mathrm{FeSO}_{4} \cdot 7 \mathrm{H}_{2} \mathrm{O} 0.05 \mathrm{gl}^{-1}$, $\mathrm{MnSO}_{4} .7 \mathrm{H}_{2} \mathrm{O} 0.01 \mathrm{gl}^{-1}, \mathrm{MgSO}_{4} 0.01 \mathrm{gl}^{-1}, \mathrm{NaCl} 0.02 \mathrm{gl}^{-1}, \mathrm{CaCl}_{2} 0.01 \mathrm{gl}^{-1}, \mathrm{Na}_{2} \mathrm{MoO}_{4} 0.002 \mathrm{gl}^{-1}$, Yeast extract $0.05 \mathrm{gl}^{-1}$, Bromothymol Blue $2 \mathrm{mLl}^{-1}$ for $24-48 \mathrm{hrs}$ at $30^{\circ} \mathrm{C}$ in $120 \mathrm{rpm}$ on a rotary shaker (Day and Dobereiner 1976). Colour change of the medium from pale green to pale blue indicates the ability to fix atmospheric $\mathrm{N}_{2}$.

\section{S rRNA based phylogenetic analysis}

Phylogenetic analysis based on 16S rRNA sequence were performed using the MEGA 7.0 (Kumar et al. 2016) based on neighbor joining statistical method (Felsenstein 1981) and the branching support of 1000 bootstrap (Felsenstein 1985). The phylogenetic tree construction based on, $16 S$ rRNA was initially performed using the cloned sequence along with sequences retrieved from GenBank and aligned with ClustalW. The model selection was performed using MEGA 7(Kumar et al. 2016) based on the lowest Bayesian Information Criterion (BIC) value (Schwarz 1978). To compare the similarity or diversity, the nucleotide sequences of 40 selected Rhizobium, Bacillus, Ralstonia, Lactococcus species from different geographical regions were retrieved from NCBI, GenBank (http:/www.ncbi.nlm.nih.gov/ ). The list of sequences retrieved from NCBI with strain name, accession number and locations are given in online resource 1.

\section{Statistical analysis}

Using the SPSS software (27.0V, SPSS, Chicago, USA), one way ANOVA was performed to analyze the concentration of IAA in the isolates after $48 \mathrm{hrs}$. Statistical analysis was carried out according to Turkey's test $(P \leq 0.05)$. The data were an average of 4 separate experiments with three replicates $(n=3)$.

\section{Results}

\section{Isolation and CHNS elemental analysis}


Four nodules associated bacteria were isolated from the healthy nodules of $M$. pudica. The isolates were purified and subcultured on nutrient agar medium ( $\mathrm{pH}-7)$. CHNS analysis of the rhizosphere soil showed nitrogen $(0.274 \%)$, carbon $(1.534 \%)$, hydrogen $(2.094 \%)$ and sulphur $(0 \%)$. The soil was acidic to slightly neutral with a mean $\mathrm{pH}$ value of $6.49 \pm 0.1$.

\section{Phenotypic characterization}

Phenotypic characteristics of the four isolates are presented in Table 1.

Table 1

Morphological, biochemical and physiological features of the four isolates extracted from root nodules of Mimosa pudica

\begin{tabular}{|c|c|c|c|c|}
\hline $\begin{array}{l}\text { Phenotypic } \\
\text { characterization }\end{array}$ & $\begin{array}{l}\text { Rhizobium sp. } \\
\text { CU8 }\end{array}$ & $\begin{array}{l}\text { Bacillus cereus } \\
\text { MY5 }\end{array}$ & $\begin{array}{l}\text { Ralstonia pickettii } \\
\text { MY1 }\end{array}$ & $\begin{array}{l}\text { Lactococcus } \\
\text { lactis MY3 }\end{array}$ \\
\hline \multicolumn{5}{|c|}{ Morphological Features } \\
\hline Gram staining & gram negative & gram positive & gram negative & gram negative \\
\hline Motility & motile & motile & motile & non-motile \\
\hline Spore production & $\begin{array}{l}\text { non } \\
\text { sporulating }\end{array}$ & sporulating & non sporulating & non sporulating \\
\hline \multicolumn{5}{|l|}{ Biochemical Features } \\
\hline Indole production & + & + & + & + \\
\hline Hydrolysis of urea & + & + & + & + \\
\hline Methyl red (MR) test & - & - & - & + \\
\hline $\begin{array}{l}\text { Voges proskauer } \\
\text { (VP) }\end{array}$ & + & + & + & - \\
\hline Citrate utilization & + & + & + & + \\
\hline Nitrate reduction test & + & + & - & - \\
\hline $\begin{array}{l}\text { Antibiotic } \\
\text { susceptibility }\end{array}$ & TE,PG, Amp & TE, PG, Amp & TE, PG & TE, PG, Amp \\
\hline
\end{tabular}

\section{Molecular characterization}

\section{DNA extraction, 16S ribosomal RNA typing and sequencing}

Genomic DNA was extracted from the four isolates using CTAB method. The 260/280 ratio of the DNA samples were 1.8-2 indicating the purity of the samples. Molecular characterization by 16S rRNA confirmed that the four isolates are Rhizobium sp. CU8, B. cereus MY5, R. pickettii MY1 and L. lactis MY3. 
The 16S rRNA gene from the Rhizobium sp. CU8, B. cereus MY5, R. pickettii MY1 and L. lactis MY3 possessed $99-100 \%$ homology with the nucleotide sequence of other species retrieved from NCBI. $L$. lactis MY3 from the root nodules of $M$. pudica are not reported earlier. GenBank accession numbers were provided for the 16S rRNA gene sequence of Rhizobium sp. CU8 (MN744368), B. cereus MY5 (MH997483), R. pickettii MY1(MH997486) and L. lactis MY3 (MW132401).

\section{Characterization of plant growth promoting activities}

\section{(a). IAA production potential of the isolates}

IAA production during the $48 \mathrm{hr}$ of growth was quantified in Rhizobium sp. CU8, B. cereus MY5, R. pickettii MY1 and L. lactis MY3 using Salkowski reagent. R. pickettii MY1 and Rhizobium sp. CU8 developed colour reaction immediately after the addition of reagents indicating the formation of IAA and better IAA production was observed when the cultures were incubated for $25 \mathrm{~min}$ in dark. The highest quantity of IAA was produced in R. pickettii MY1 $(49.8630 \pm 0.1779 \mu \mathrm{g} / \mathrm{mL})$ followed by $B$. cereus MY5 $(13.5159 \pm$ $0.2416 \mu \mathrm{g} / \mathrm{mL})$, Rhizobium sp. CU8 $(11.6895 \pm 0.1837 \mu \mathrm{g} / \mathrm{mL})$ and L. lactis MY3 $(4.9315 \pm 0.0790$ $\mu \mathrm{g} / \mathrm{mL}$ ) (Fig. 1) after 48hrs of incubation, which was significant at $\mathrm{P}<0.05$.

\section{(b). Production of organic acid}

Among the four isolates, L. lactis MY3 showed a clear zone after $24 \mathrm{hrs}$ of incubation due to the degradation of calcium carbonate leading to the production of organic acid. Other three isolates doesn't show any clear zone around the colony.

\section{(c). Nitrogen fixing potential of the isolates}

The four isolates, Rhizobium sp. CU8, B. cereus MY5, R. pickettii MY1 and L. lactis MY3 exhibited $\mathrm{N}_{2}$ fixing ability grown in nitrogen free malate medium containing bromothymol blue as indicator. The Rhizobium sp. CU8, B. cereus MY5 and R. pickettii MY1 showed significant colour change from pale green to pale blue indicating $\mathrm{N}_{2}$ fixing ability within 24hrs. However, L. lactis MY3 developed the colour change only after $48 \mathrm{hrs}$.

\section{Phylogeny based on 16S rRNA gene}

The cloned sequence and the sequences retrieved from the GenBank were used to construct the phylogenetic tree using Neighbor Joining $(\mathrm{NJ})$ method with 1000 bootstraps. Models with the lowest BIC scores were considered to describe the best nucleotide substitution pattern. The TN93 + G (Tamura Nei Model) displayed the lowest BIC scores (10125.617- online resource 2) to construct consensus NJ tree from the aligned sequences (Fig. 2). The multiple sequence alignment based phylogram using MEGA 7.0 and TN93 + G model based on bootstrap analysis of 1000 replicates was performed to estimate the confidence of the tree topologies. The phylogenetic position of the Rhizobium sp. CU8, B. cereus MY5, $R$. pickettii MY1 and L. lactis MY3 in relation to other species of this genus is illustrated in Fig. 2; the numbers adjacent to nodes are the statistical frequency of the indicated species. 
The genus Rhizobium and Ralstonia fall under the same phylum proteobacteria classified as subclass $a$ and $\beta$ proteobacteria. Based on 16S rRNA homology, both genera are placed in separate group originated from a single node. $L$. lactis and $B$. cereus were grouped as a separate clade.

Phylogenetic tree revealed that Rhizobium sp. CU8 and B. cereus MY5, showed highest relatedness with other members of the genus. Rhizobium sp. CU8 shows closest relatedness with Indian Rhizobium sp. S19. B. cereus MY5 shows highest similarity to $B$. subtilis IMG04 from India among other members of this genus. In the case of $R$. pickettii $\mathrm{MY} 1$ and L. lactis $\mathrm{MY} 3$, the maximum similarity of these two native strains were shown to $R$. pickettii CP12 from China and L. lactis KUMS-T18 from Iran.

Group I Rhizobium sp. CU8 and Group II Ralstonia pickettii MY1 showed 100\% bootstrap support within the genus level. L. lactis MY3 in Group III is tightly clustered with L. lactis KUMS-T18 with bootstrap support $98 \%$. In Group IV, B. cereus MY5 clustered with B. subtilis IMG04 with bootstrap support (>50\%). However, none of the isolates that clustered in different phylogenetic trees based on 16S rRNA analysis.

\section{Discussion}

The interaction between rhizobia and other nodule associated bacteria are of relevance in the improvement of $\mathrm{N}_{2}$ fixation and plant growth promotion in leguminous plants (Barea et al. 2005; Ryu et al. 2005). The isolation, characterization and phylogenetic relationship of newly identified bacteria from root nodule of $M$. pudica illustrated the $\mathrm{N}_{2}$-fixation and PGP activity of these isolates. The isolation procedure consists of nodule surface sterilization specifically aimed to allow the obtention of nodule endophytes (Rajendran et al. 2008) resulting in the isolation of three non-rhizobial bacteria from $M$. pudica nodule. In the past, bacteria isolated from the nodules with dissimilar growth and appearance to that of typical rhizobia were considered as contaminants and discarded, however, recent studies convincingly demonstrated the occurrence of non-rhizobial bacteria in the nodules and their role on the host plants, rhizobial strains or the symbiosis are under investigation (Martínez-Hidalgo and Hirsch 2017). It is now well recognized that non-rhizobial bacteria can promote plant growth by an array of mechanisms including solubilization and mobilization of nutrients (Srivastwa et al. 2014), $\mathrm{N}_{2}$-fixation (Castellano-Hinojosa et al. 2016), production of phytohormones (Chinnaswamy et al. 2018), along with microbial processes. Nodule endophytes belonging to the genera Bacillus, Burkholderia, Pseudomonas and Enterobacter have been isolated from different legumes (Dudeja et al. 2012; Martínez-Hidalgo and Hirsch 2017).

The morphological and microscopic features of the isolates were in congruence with the earlier reports. All the isolates were sensitive to standard antibiotics suggesting their prevention mechanisms. The isolates, R. pickettii MY1, L. lactis MY3, B. cereus MY5 and Rhizobium sp. CU8 exhibited important agrobiotechnological properties, such as nitrate reduction, production of organic acid, indole acetic acid and ability to fix $\mathrm{N}_{2}$. Interestingly, urease activity was also observed in the isolates, indicating the importance of consortia with $\mathrm{N}_{2}$ fixing bacteria as a requirement for survival (Chibeba et al. 2020). 
The present result confirms the nitrogen fixation ability of $R$. pickettii MY1, B. cereus MY5, Rhizobium sp. CU8 and L. lactis MY3. Zhao et al. (2011) reported endophytic non-rhizobial Bacillus cereus and Ralstonia spp. are potent $\mathrm{N}_{2}$ fixers (Bulut 2013). The genus Rhizobium is the first bacteria participating in nitrogen fixation in legumes (Lindström and Mousavi 2020).

L. lactis MY3 is a rare observation from the root nodule of $M$. pudica and can be used as an agent for plant growth promotion (Lamont et al. 2017). According to Higdon et al. (2020), Lactococcal bacteria exists as a diazotroph in maize without nifHDKENB homologs, and hypothesized that $L$. lactis isolates from the mucilage microbiota of Sierra Mixe maize possess genes enabling BNF activity and elucidated that all the important genes for the BNF trait in L. lactis underpinning the ability to fix atmospheric nitrogen present in the mucilage-derived lactococci, which supports the hypothesis that lactococci can exist as diazotrophs. L. lactis MY3 develop organic acid indicating the interactions between PGPR and plants can enhance the secretion of organic acids, which play an important role in the process of the activation and absorption of insoluble nutrients by plants (Pii et al. 2015).

A diverse group of microbes, including free living, epiphytic and tissue colonizing bacteria synthesize IAA (Patten and Glick 1996). The four strains produced considerable quantity of IAA, which is comparable with earlier studies on various bacteria including Rhizobium sp., B. cereus, R. pickettii and L. lactis ( Kumar and Ram 2012; Kuklinsky-Sobral et al. 2004; Mohite 2013; Strafella et al. 2021). According to Datta and Basu (2000), most of the studies reported that IAA producing organisms are gram negative, however, few Bacillus known to produce IAA which is gram positive strains (Wahyudi et al. 2011). Present study showed that B.cereus MY5 is IAA producing gram positive bacteria.

The evolutionary history was derived using the neighbor joining method based on the Tamura-Nei model (Tamura and Nei 1993). The bootstrap consensus tree developed from 1000 replicates represented the evolutionary history of the taxa analyzed (Felsenstein 1985). Branches corresponding to partitions reproduced in less than $50 \%$ bootstrap replicates are collapsed. The percentage of replicate trees in which the associated taxa clustered together in the bootstrap test (1000 replicates) is shown next to the branches (Felsenstein 1985). Rhizobium sp. CU8 and B. cereus MY5 showed highest similarity with native strains.

\section{Conclusions}

This study reports the isolation, molecular identification, characterization and phylogenetic relationship of the Rhizobium sp. CU8, R. pickettii MY1, L. lactis MY3, and B. cereus MY5 from the root nodule of $M$. pudica. The biochemical analysis confirms the nitrogen fixing potential, plant growth promotion and other potential microbial activities of the obtained isolates. The bacteria with $\mathrm{N}_{2}$ fixing capacity act as plant growth promoters hence can be used as biofertilizers. L. lactis strain MY3 is a new report from the root nodule of M. pudica with plant growth promotion and $\mathrm{N}_{2}$ fixation capacity. Phylogenetic analysis using neighbor joining method showed the relatedness and evolutionary position of the isolates with native strains as well as other geographical locations retrieved from NCBI. The analysis showed that non- 
rhizobial bacteria, L. lactis MY3 and B. cereus MY5 may co-exist with Rhizobium sp. CU8 and R. pickettii MY1 in the root nodule of $M$. pudica.

However, it requires further studies to assess the role of these isolates in $\mathrm{N}_{2}$ fixation and plant growth promotion under pot culture as well as in field condition and these can be used as a potential biofertilizer.

\section{References}

1. Ausubel FM, Brent R, Kingston RE, Moore DD, Seidman JG, Smith JA, Struhl K (1995) Short Protocols in Molecular Biology. $3^{\text {rd }}$ edn. John Wiley \& Sons Inc. 2.11- 2.12.

2. Barea JM, Pozo MJ, Azco'n R, Azco'n-Aguilar C (2005) Microbial co-operation in the rhizosphere. J Exp Bot 56:1761-1778. https://doi.org/10.1093/jxb/eri197

3. Bergey DH (2001) Bergey's Manual ${ }^{\circledR}$ of Systematic Bacteriology. Springer Science \& Business Media 2.

4. Bulut S (2013) Evaluation of efficiency parameters of phosphorous-solubilizing and N-fixing bacteria inoculations in wheat (Triticum aestivum L.). TURK J AGRIC FOR 37(6):734-743. https://doi.org/10.3906/tar-1301-112

5. Cappuccino JG, Sherman N, Microbiology A (1983) A laboratory manual. Addision-1999.

6. Castellano-Hinojosa A, Correa-Galeote D, Palau J, Bedmar EJ (2016) Isolation of $\mathrm{N}_{2}$-fixing rhizobacteria from Lolium perenne and evaluating their plant growth promoting traits. J Basic Microbiol 56(1):85-91. https://doi.org/10.1002/jobm.201500247

7. Chibeba AM, Pereira CS, Antunes JEL, Ribeiro RA, de Almeida Lopes AC, Gomes RLF, Hungaria M, Araujo ASF (2020) Polyphasic characterization of nitrogen-fixing and co-resident bacteria in nodules of Phaseolus lunatus inoculated with soils from Piauí State, Northeast Brazil. SYMBIOSIS 80(3): 279292. https://doi.org/10.1007/s13199-020-00672-1

8. Chinnaswamy A, Coba de la Peña T, Stoll A, de la Peña RD, Bravo J, Rincón A, Lucas M, Pueyo J (2018) A nodule endophytic Bacillus megaterium strain isolated from Medicago polymorpha enhances growth, promotes nodulation by Ensifer medicae and alleviates salt stress in alfalfa plants. Ann Appl Biol 172(3):295-308. https://doi.org/10.1111/aab.12420

9. Datta C, Basu PS (2000) Indole acetic acid production by a Rhizobium species from root nodules of a leguminous shrub, Cajanus cajan. Microbiol Res 155(2):123-127. https://doi.org/10.1016/S09445013(00)80047-6

10. Döbereiner J, Day JM (1976) Associative symbioses in tropical grasses: characterization of microorganisms and dinitrogen-fixing sites. In Proceedings of the 1 st international symposium on nitrogen fixation, Washington State University Press, Pullman 2:518-538

11. Downing KJ, Thomson JA (2000) Introduction of the Serratia marcescens chiA gene into an endophytic Pseudomonas fluorescens for the biocontrol of phytopathogenic fungi. Can J Microbiol 46:363-369. https://doi.org/10.1139/w99-147 
12. Dudeja S, Giri R, Saini R, Suneja-Madan P, Kothe E (2012) Interaction of endophytic microbes with legumes. J Basic Microbiol 52(3):248-260. https://doi.org/10.1002/jobm.201100063

13. Felsenstein $\mathrm{J}$ (1981) Evolutionary trees from gene frequencies and quantitative characters: finding maximum likelihood estimates. Evolution 1229-1242. https://doi.org/10.2307/2408134

14. Felsenstein J (1985) Confidence limits on phylogenies: An approach using the bootstrap. Evol 39:783-791. https://doi.org/10.1111/j.1558-5646.1985.tb00420.x

15. Glick BR (1995) The enhancement of plant growth by free living bacteria. Can J Microbiol 41:109117. https://doi.org/10.1139/m95-015

16. Gopalakrishnan S, Sathya A, Vijayabharathi R, Varshney RK, Gowda CL, Krishnamurthy L (2015) Plant growth promoting rhizobia: challenges and opportunities. 3 Biotech 5(4):355-377. https://doi.org/10.1007/s13205-014-0241-x

17. Gordon SA, Weber RP (1951) Colorimetric estimation of indole acetic acid. Plant physiol 26(1):192. https://dx.doi.org/10.1104\%2Fpp.26.1.192

18. Higdon SM, Huang BC, Bennett AB, Weimer BC (2020) Identification of Nitrogen Fixation Genes in Lactococcus Isolated from Maize Using Population Genomics and Machine Learning.

Microorganisms 8(12):2043. https://doi.org/10.3390/microorganisms8122043

19. Higdon SM, Pozzo T, Kong N, Huang BC, Yang ML, Jeannotte R, Weimer BC et al (2020) Genomic characterization of a diazotrophic microbiota associated with maize aerial root mucilage. PLoS one 15(9):e0239677. https://doi.org/10.1371/journal.pone.0239677

20. Kloepper JW (1992) Plant growth-promoting rhizobacteria as biological control agents. Soil microbial ecology: applications in agricultural and environmental management 255-274

21. Kobayashi DY, Palumbo JD (2000) Bacterial endophytes and their effects on plants and uses in agriculture. Microbial endophytes 19:199-233

22. Kuklinsky-Sobral J, Araújo WL, Mendes R, Geraldi IO, Pizzirani-Kleiner AA, Azevedo JL (2004) Isolation and characterization of soybean-associated bacteria and their potential for plant growth promotion. Environ Microbiol 6(12):1244-1251. https://doi.org/10.1111/j.1462-2920.2004.00658.x

23. Kumar PR, Ram MR (2012) Production of indole acetic acid by Rhizobium isolates from Vigna trilobata (L) Verdc. Afr J Microbiol Res 6(27):5536-5541. https://doi.org/10.5897/AJMR11.105

24. Kumar S, Stecher G, Tamura K (2016) MEGA7: molecular evolutionary genetics analysis version 7.0 for bigger datasets. Mol Biol Evol 33(7):1870-1874. https://doi.org/10.1093/molbev/msw054

25. Lamont JR, Wilkins O, Bywater-Ekegärd M, Smith DL (2017) From yogurt to yield: Potential applications of lactic acid bacteria in plant production. Soil Biol Biochem 111:1-9. https://doi.org/10.1016/j.soilbio.2017.03.015

26. Lane DJ (1991) 16S/23S rRNA sequencing. Nucleic acid techniques in bacterial systematics 115-175

27. Lindström K, Mousavi SA (2020) Effectiveness of nitrogen fixation in rhizobia. Microb Biotechnol 13(5):1314-1335. https://doi.org/10.1111/1751-7915.13517 
28. Martínez-Hidalgo P, Hirsch AM (2017) The nodule microbiome: $\mathrm{N}_{2}$-fixing rhizobia do not live alone. Phytobiomes 1(6):7082. https://doi.org/10.1094/PBIOMES-12-16-0019-RVW

29. Mohite $B$ (2013) Isolation and characterization of indole acetic acid (IAA) producing bacteria from rhizospheric soil and its effect on plant growth. Soil Sci Plant Nutr 13(3):638-649. http://dx.doi.org/10.4067/S0718-95162013005000051

30. Parmar N, Dadarwal KR (1999) Stimulation of nitrogen fixation and induction of flavonoid-like compounds by rhizobacteria. J Appl Microbiol 86:36-64. https://doi.org/10.1046/j.13652672.1999.00634.x

31. Patten CL, Glick BR (1996) Bacterial biosynthesis of indole-3-acetic acid. Can J Microbiol 42(3):207220. https://doi.org/10.1139/m96-032

32. Peix A, Ramírez-Bahena MH, Velázquez E, Bedmar EJ (2015) Bacterial associations with legumes. CRC Crit Rev Plant Sci 34(1-3):17-42. https://doi.org/10.1080/07352689.2014.897899

33. Pii Y, Penn A, Terzano R, Crecchio C, Mimmo T, Cesco S (2015) Plant-microorganism-soil interactions influence the Fe availability in the rhizosphere of cucumber plants. Plant Physiol Biochem 87:45-52. https://doi.org/10.1016/j.plaphy.2014.12.014

34. Rajendran G, Patel MH, Joshi SJ (2012) Isolation and characterization of nodule-associated Exiguobacterium sp. from the root nodules of fenugreek (Trigonella foenum-graecum) and their possible role in plant growth promotion. Int J Microbiol. https://doi.org/10.1155/2012/693982

35. Rajendran G, Sing, F, Desai AJ, Archana G (2008) Enhanced growth and nodulation of pigeon pea by co-inoculation of Bacillus strains with Rhizobium spp. Bioresour Technol 99(11):4544-4550. https://doi.org/10.1016/j.biortech.2007.06.057

36. Ryu CM, Kim JW, Choi OH, Park SY, Park SH, Park CS (2005) Nature of a root associated Paenibacillus polymyxa from field-grown winter barley in Korea. J Microbiol Biotechnol 15:984-991

37. Schwarz G (1978) Estimating the dimension of a model. Ann Stat 6(2):461-464. https://doi.org/10.1214/aos/1176344136

38. Srivastwa PK, Kanhaiyaji V, Nishi K (2014) Growth promotion of plant by nutrient mobilizing PGPR of salt-affected soil. Asian J Soil Sci 9(1):126-129

39. Strafella S, Simpson DJ, Yaghoubi Khanghahi M, De Angelis M, Gänzle M, Minervini F, Crecchio C (2021) Comparative Genomics and In Vitro Plant Growth Promotion and Biocontrol Traits of Lactic Acid Bacteria from the Wheat Rhizosphere. Microorganisms 9(1):78. https://doi.org/10.3390/microorganisms9010078

40. Sturz AV, Christie BR, Matheson BG, Arsenault WJ, Buchanan NA(1999) Endophytic bacterial communities in the periderm of potato tubers and their potential to improve resistance to soil-borne plant pathogens. Plant Pathol 48(3):360-369. https://doi.org/10.1046/j.1365-3059.1999.00351.x

41. Tamura K, Nei M (1993) Estimation of the number of nucleotide substitutions in the control region of mitochondrial DNA in humans and chimpanzees. Mol Biol Evol 10:512-526 https://doi.org/10.1093/oxfordjournals.molbev.a040023 
42. Vincent JM (1970) A manual for the practical study of the root-nodule bacteria. Blackwell scientific publication, Oxford.

43. Wahyudi AT, Astuti RP, Widyawati A, Mery A, Nawangsih AA (2011) Characterization of Bacillus sp. strains isolated from rhizosphere of soybean plants for their use as potential plant growth for promoting rhizobacteria. J Microbiol Antimicrob 3(2):34-40. https://doi.org/10.5897/JMA.9000020

44. Zgadzaj R, James EK, Kelly S, Kawaharada Y, de Jonge N, Jensen DB, Madsen LH, Radutoiu S (2015) A legume genetic framework controls infection of nodules by symbiotic and endophytic bacteria. PLoS Genet 11(6):e1005280. https://doi.org/10.1371/journal.pgen.10052803

45. Zhao L, Xu Y, Sun R, Deng Z, Yang W, Wei G (2011) Identification and characterization of the endophytic plant growth prompter Bacillus cereus strain MQ23 isolated from Sophora alopecuroides root nodules. Braz J Microbiol 42(2):567-575. https://dx.doi.org/10.1590\%2FS1517838220110002000022

\section{Figures}

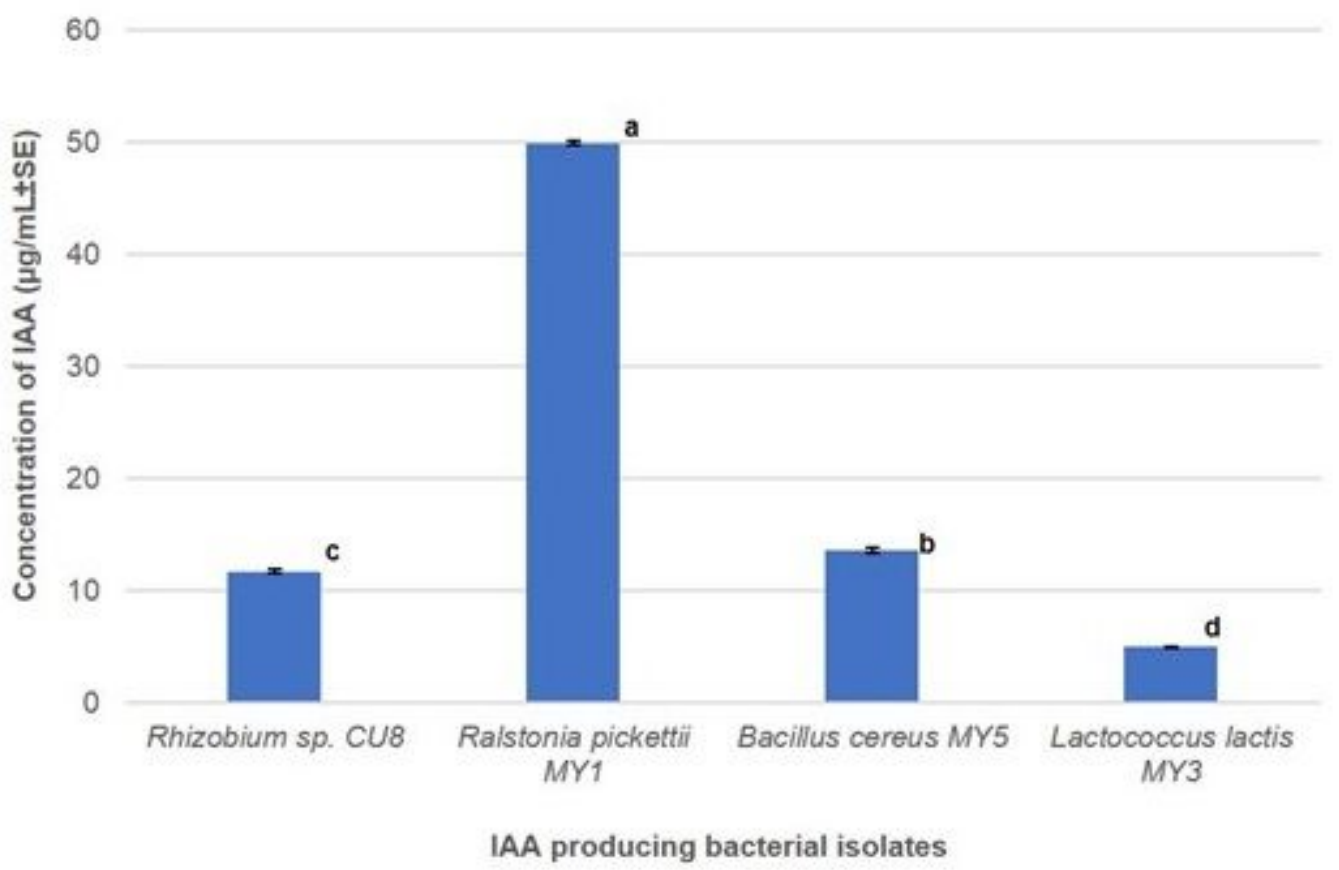

\section{Figure 1}

The quantity of IAA produced in different bacteria spp. isolated during 48hrs of culture. The different letters indicates the significant difference at the $P<0.05$ level. Values are given as mean $\pm S E$ for each sample 


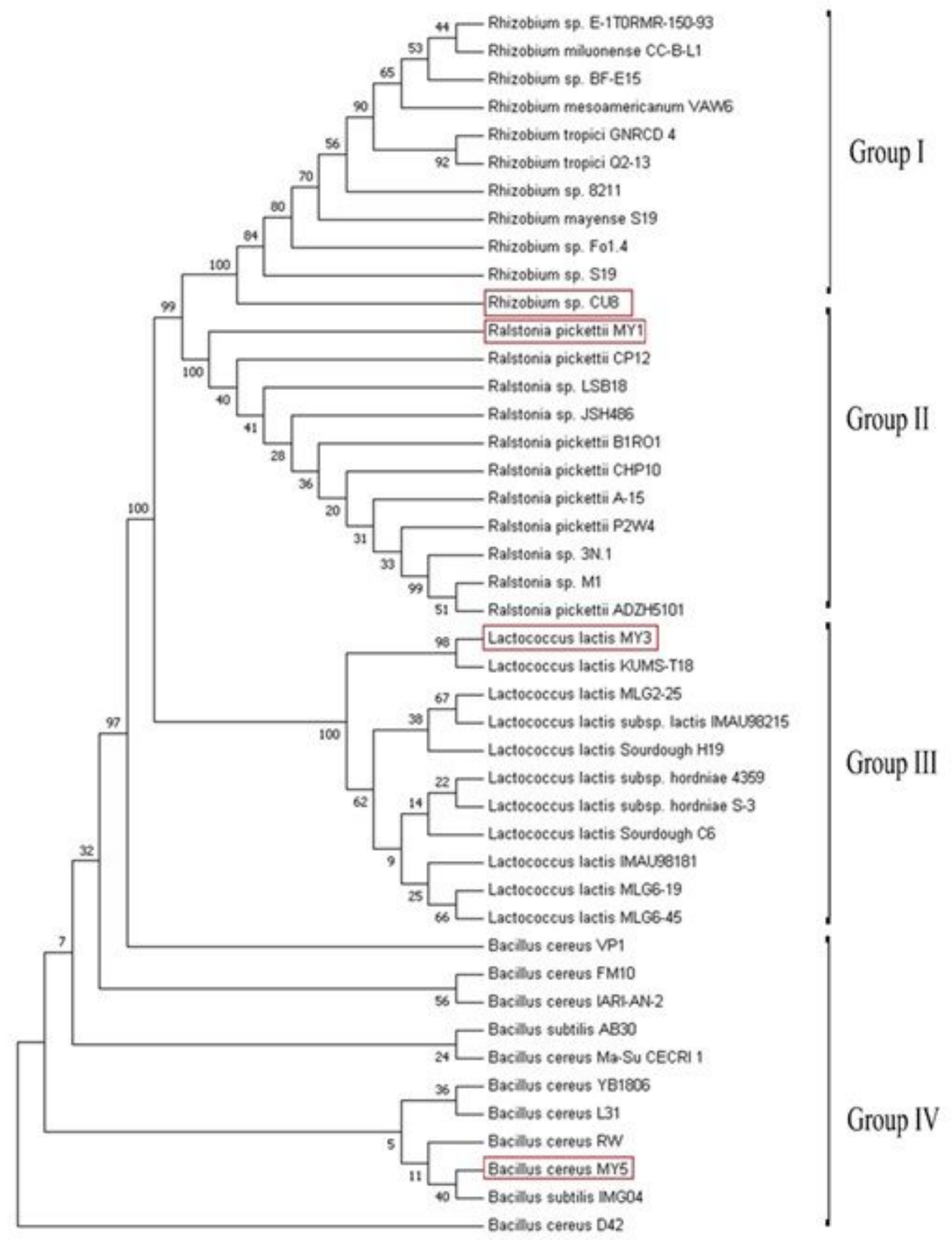

Figure 2

Neighbor joining tree constructed using 16S rRNA gene sequences of isolates and the homologous gene sequences retrieved from NCBI with homologous sequences obtained from NCBI. The species represented in boxes indicates the isolates from the study

\section{Supplementary Files}

This is a list of supplementary files associated with this preprint. Click to download.

- supplementarymaterial2.doc 
- suppllementarymaterial1.doc

Page 15/15 